\title{
INTERNALIZATION OF ISLAMIC MODERATION VALUES IN PAI LEARNING AT SMA MA'ARIF NU 1 BANYUMAS
}

\author{
M. Misbah \\ IAIN Purwokerto \\ Jl. A. Yani No. 40A Purwokerto, Indonesia, 53126 \\ Email:misbah@iainpurwokerto.ac.id \\ Ikhsan Nur Fahmi \\ IAIN Purwokerto \\ Jl. A. Yani No. 40A Purwokerto, Indonesia, 53126 \\ Email:ikhsannurfahmi5@gmail.com \\ Article received January $3^{\text {rd }}, 2021$; Article revised April 12 $2^{\text {th }}, 2021$; Article approved May $8^{\text {th }}, 2021$

\begin{abstract}
Schools are one of the right places to spread the sensitivity of students on a different variety. SMA Ma'arif NU 1 Banyuma, as an educational institution, is able to internalize the Islamic moderation values of students through various activities in the school. This research aims to uncover and analyze the internalization of Islamic moderation values in the study of Islamic Religious Education (PAI) at SMA Ma'arif NU 1 Banyumas. The type of research is field research. Data mining was obtained through interviews with informants. The observation was conducted to see PAI learning activities and education in and out of the classroom, as well as PAI learning documentation. Data triangulation was used for the validation of the obtained data. Data analysis techniques were through three steps; data reduction, data display, and conclusion drawing. The results of this study are the values of Islamic moderation internalized in PAI learning are the values of al-'adālah, tawāzun, tasāmuh. The internalization process is carried out through transformational value, transactional value, and transinternalization value. The strategies used are introduction, habituation, civility, and practice. The implications show that students are used to performing worship, respecting teachers and friends, social caring, being tolerant, being discipline, being environmentally responsible, and obeying the rules.
\end{abstract}

Keywords: internalization, islamic moderation, PAI learning.

\section{INTRODUCTION}

$\mathrm{R}$ eligious education is one of the mandatory subjects that must be included in the formal education curriculum in Indonesia. This is based on the National Education System Law No. 20 of 2003 article 37 paragraph (2) which states that the education curriculum must contain religious education, citizenship education, and language education. These three subjects become mandatory because they are aligned with the national educational objectives that seek to realize Indonesian people who believe, respect differences and nationalists (DIKBUD, 2003). One of the religious educations that must be taught in Islamic educational institutions is Islamic religious education (PAI) (Misbah, 2019b:15-16; Muhaimin, 2001). It is part of the national education system which becomes a compulsory subject in every Islamic educational institution because religious life is a dimension of life that is expected to manifest in an integrated manner.

PAI's goal is to increase the belief, understanding, appreciation and practice of students about Islam so that they become Muslims who believe and fear Allah SWT and have noble character in personal life, society, nation, and state and to continue education at a higher level (Anwar, 2014: 14). However, the current reality seems to be that the purpose of PAI is far from the expectation. The phenomenon of high cases of juvenile delinquency, the rise of hate speech on social media, the practice of bullying both through social media and in schools, the spread of hoax news (Beryandhi, 2020), acts of terrorism, the spread of radical understanding in the community, as well as the many intolerant 
actions in religion (Carina, 2019), at least become indicators of the unattainable learning objectives of Islamic religious education (PAI). From there, the national standard of Islamic religious education (SNPAI) was born.

SNPAI emerged from the government's concerns over various criticisms of PAI in schools. There are at least four criticisms that appear; first, criticisms related to morality. Criticism related to the competence of graduates who have not been able to read the Quran and know it's meaning as a second criticism. Further criticism considers that the school has not been able to perform ritual activities properly, such as prayer. The fourth criticism is the criticism about school graduates from elementary to secondary school level who are still lacking in their knowledge of Islam (Nuqtoh, 2015). These four criticisms are the driving force behind the birth of SNPAI in school".

Especially criticism about morality, as a description for example, is still often the emergence of students who commit acts of violence such as bullying against fellow students both inside and outside of school; lack of manners among students; the influx of drugs and alcohol among students, as well as the frequent occurrence of cases of free sex culture among students (Muslim, 2019: 211-224). In order to cope with these problems, another concern is the issue of exclusive religious insights and paradigms that have touched some students. This is proved by some students involved in radicalism activities or movements (Ismail et al., 2019: 171). These indicators raises questions about the role of Islamic religious education (PAI) so far in the formation of a moderate human being.

The mainstreaming of the Islamic moderation movement is in line with the government's vision-mission contained in the RPJMN (National Medium-Term Development Plan) 2020-2024, it is appropriate for educational institutions to be the vanguard in internalizing the moderation movement through learning. Islamic moderation, in general, can be interpreted as an attitude to take the middle path in religion, not extreme left (radical) and not extreme right (liberal), so Islamic moderation is the way in holding a religion moderately, not extreme (Saefudin, 2018). Islamic moderation is important to be implemented in life because the Indonesian nation is so plural and multicultural.

Diversity in Indonesia that is so plural, on the other hand, can also be a social force that is so beautiful if mutually respected. At the same time, diversity in Indonesia can also be a potential social conflict if the community no longer upholds the principle of "Bhinneka Tunggal Ika (Unity in Diversity)" as a guideline for the unity of the Indonesian nation (Amaliyah, 2020: 327-329).

Teachers have a crucial role in countering radical and intolerant understanding in educational institutions. Although there are curriculum, textbooks, and school management, in these institutions, it is the role of teachers that is very decisive in the learning process. In PAI learning, the attitude of teacher in delivering the learning material must convey an Islamic moderation attitude that is tawazzun (balanced). If there are differences of views on a problem in the learning material, such as in figh subjects, then PAI teachers must deliver in a balanced manner. The point is that a teacher should express an opinion from only one particular sect's view, but the teacher should express opinions from various opinions of other sects. Therefore, PAI teacher must be neutral in delivering the subject matter, not only conveys understanding or opinion about a problem that comes from his group's sect. It should be conveyed various views from other groups comprehensively. Thus, the teacher will provide extensive knowledge for the students and teach them about the value of tolerance to respect each other's differences.

In educational institutions, Islamic moderation values must be internalized to the students. This is because educational institutions can potentially share various ism, both the embryo of radicalism, exclusionism as well as the antidote to radicalism (inclusionism), and moderatism (Yunita, 2005), among others by spreading Islamic moderation values. This can be done in three ways as stated by Toto Suharto by adopting Gerald L Gutek's concept of educational ideology which stated Islamic moderation values can be internalized through the determination of education policies and objectives, in the formulation itself, as well as in the delivery of values hidden in the hidden curriculum (Suharto, 2017). 
The internalization of Islamic moderation values is applied in educational institutions in the framework of preventive measures and counter the possibility of the emergence of various radical and intolerant understandings (Muslim, et.al., 2019). A number of survey explain that there are three main doors in the way of radical and intolerant understanding that insinuates the school environment; first through extracurricular activities, secondly, through the role of teachers in the teaching and learning process, and thirdly, through a weak school curriculum in preventing the entry of radical and intolerant understanding in schools (Penyusun, 2019: 147). Thus, moderation movement is very urgent in the world of education because the role of the teachers is very important to instill the values of Islamic moderation through its learning curriculum (Suprapto, 2020: 358359).

The current learning curriculum is the 2013 curriculum. Curriculum 2013 is a curriculum based on character and competence. The purpose of the 2013 curriculum is to shape Indonesian people to have the ability to live as individuals and citizens who are faithful, productive, creative, innovative, and effective and able to contribute to society, nation, state, and civilization of the world. In the 2013 curriculum, there were two modes of learning, namely direct learning, and indirect learning. The direct learning process is an educational process in which learners develop knowledge, thinking skills and psychomotor skills through direct interaction with learning resources designed in the syllabus and RPP in learning activities. Indirect learning is an educational process that occurs during the direct learning process but is not designed in certain activities (KEMENDIKBUD RI, 2014).

Indirect learning regarding the development of values and attitudes intends that in the learning, PAI Islamic moderation values can be internalized through direct learning or indirect learning that are both integrated. One of educational institutions that have internalized Islamic moderation values for its students through PAI learning is SMA Ma'arif NU 1 Kemranjen Banyumas. Internalization of Islamic moderation values for students is carried out through various activities in the school. This is the focus of this research.
Studies on the values of Islamic moderation have been widely studied in various perspectives and objects. This is because the issue of religious moderation is very urgent and sensitive as a study afterall it relates to religious life. Harto and Tastin conducted a study on "Development of Wasatiyah Islamic-Minded PAI Learning: Efforts to Build Religious Moderation Attitudes of Learners". From this library research, the results show that PAI learning should use a contextual scientific approach because this approach can be applied in three areas of education, namely attitude, knowledge, and skills. The expected result of PAI learning with this approach is students become more aware of their religious teachings and the reality of other religious teachings (Harto \& Tastin, 2019). Purwanto, et al. conducted research with a study on "Internalization of The Value of Moderation Through Islamic Religious Education in Public Universities". The result of his research shows that the pattern of internalization of moderation values through PAI courses at UPI Bandung. The material is adapted to the input of students, the competence of lecturers and support from the UPI campus environment. Curriculum designed in accordance with the provisions of PT. The internal method is done face-to-face in learning, tutorials, seminars and such type of activities. The evaluation is done through screening the Islamic knowledge insights orally and written periodically by lecturers and tutors (Purwanto et al., 2019). The third is Hiqmatunnisa and Az Zafi's study on "The Application of Islamic Moderation Values in Fiqh Learning at PTKIN Using the Concept of Basic Learning Problem". The result shows that learning Fiqh with PBL method in PT can be a forum to internalize the values of Islamic moderation because it opens students' insights to think openly to see various perspectives of Islamic law to position themselves to be in the middle and moderate in the community (Hiqmatunnisa \& Zafi, 2020).

The formulation of the problem focused on how to internalize the values of Islamic moderation in the learning of PAI at SMA Ma'arif NU 1 Kemranjen Banyumas; how the internalization process is implemented; and how the internalization strategy conducted and how the implications of internalization of Islamic moderation values toward the social attitudes of students. 
In line with these problems, this study aims to examine the values of Islamic moderation internalized in PAI learning in the school, its internalization process, internalization strategy, and the implications of internalization of Islamic moderation values to students social attitudes. Based on this purpose, the significance of this research becomes urgent to provide benefits to teachers and people who are consistent in the world of Islamic religious education related to the internalization of Islamic moderation values in PAI learning. Other benefits are also for parents of learners and the public to be able to obtain information about the internalization of the value of Islamic moderation, as well as for the government for policy-making related to the internalization of Islamic moderation values as a counter to radicalism, exclusionism, and fanaticism in the name of religion.

\section{RESEARCH METHOD}

This article is the result of field research using a qualitative approach (Moleong, 2010: 3). The paradigm used is post-positivism, a paradigm that positions researchers to see research problems as holistic (whole), complex, mutually influencing, dynamic, meaningful, and valuebound reality to understand the meaning of complex reality and construct meanings (Setioko, 2011). This study aims to analyze the internalization of the Islamic moderation values in the study of Islamic Religious Education (PAI) at SMA Ma'arif NU 1 Kemranjen Banyumas Regency. The subjects in this st udy were PAI teachers, vice principal of curriculum, principals, students, and parents of students at SMA Ma'arif NU 1 Kemranjen. Data were obtained through interviews from informants, observations on PAI learning activities and education inside and outside the classroom, as well as PAI learning documentation. Data source triangulation was used to validate the data obtained (Sugiyono, 2015: 330). The data analysis technique in this study used a model according to Miles \&Huberman, which consists of three stages; data reduction, data presentation, and conclusion drawing /verification (Herdyansah, 2019: 164).

\section{DISCUSSION}

The origin of the word moderation is "moderâtio", meaning "to the medium" (not excess and no shortage). The word also means self-mastery (from a very excess and deficient attitude). Moderation is the same as being moderate, namely: reduction of violence and avoidance of extremes (middle of a problem) (Penyusun, 2019). Thus, when it is said, "a person is moderate", it means that the person has a reasonable attitude, not extreme, and mediocre. In Islam itself the concept of moderation is known as wasatiyah commensurated with the meaning of tawāsut (Misbah, 2019: 102). This concept is one of the characteristics and essence of religious teachings.

The word wasatiyah has at least 3 meanings: middle, fair, and best. Whichever word is used, they all reflect the same meaning, which is fair, in this case, it choosing the middle ground position among extreme choices. These three meanings are interrelated with each other, because the attitude in the middle of it reflects a fair attitude and the best choice (Wardani, 2020). In some interpretations, the term "wasata" means the best, chosen, just, istikamah, humble, doctrinal, moderate, not extreme in temporal or ukhrawi affairs, but nevertheless tawāzun (balanced) between the two sides. In other languages, wasatiyah means something good and differs in position between two extreme poles. This has consequences, when the concept of wasatiyah is applied in daily life, then the person will not have extreme attitudes (Penyusun, 2019: 16).

Islamic moderation values in PAI learning are moderate values contained in the learning process and learning materials internalized in character education. Internalization means an effort to internalize and deepen the value in order to be ingrained in every human being. Internalization of values is carried out through coaching, guidance and others, so that students master deeply a value in accordance with the expected standards and reflected in daily behavior (Mulyasa, 2011: 167). There are at least three basic values in the formation of moderate attitudes of students that need to be developed and internalized through the PAI learning process. The three basic values are 
justice ('adālah), balance (tawāzun), and tolerance (tasāmuh).

\section{Various Internalization of Islamic Moderation Values In PAI Learning at SMA Ma'arif NU 1 Kemranjen}

The values of Islamic moderation that instilled in PAI learning are three values; 'adālah (justice), tawāzun (balance), and tasāmuh (tolerance). These refer to the principles of religious moderation initiated by the Ministry of Religious Affairs (Kementerian Agama RI, 2012: 23).

The values of Islamic moderation are internalized in PAI learning through three kinds of activities. First, through learning in the classroom, secondly, through learning religious activities, and thirdly through learning the local content of the school. Three forms of activities in the internalization are the way of SMA Ma'arif NU 1 Kemranjen in internalizing the values of Islamic moderation in students. Without the realization through activities in classroom learning, religious activities, or local content of the school, the internalization of Islamic moderation values becomes only a discourse. Of the three forms of internalization above, there was a process of internalization of islamic moderation value at SMA Ma'arif NU 1 Kemranjen.

\section{Internalization process of Islamic Moderation Value through PAI learning activities in the classroom}

In classroom learning, there is a process of internalizing the value of Islamic moderation. At SMA Ma'arif NU 1 Kemranjen, the process of internalizing the value of 'adālah (justice) included in the value of Islamic moderation demand the teachers to be fair to all students regardless of student background. Teachers guide students to be fair. First, being fair to Allah SWT by teaching what is commanded and staying away from what is forbidden. Also, being just to one self and be careful in doing things. Thirdly, being fair to others, i.e. treat others according to what is rightful and do not hurt them. Fourth, students should be fair to other living beings, in way of maintaining the environment and nature. All these activities are carried out in PAI learning when the teacher delivers learning materials through lectures or advice (Fahmi, 2020b).

The next value of Islamic moderation is tawāzun (balance) value. At SMA Ma'arif NU 1 Kemranjen in internalizing the value of tawāzun was through intracurricular and extracurricular activities as well as religious activities in schools. This is intended to maintain balance in all things, learners are not only equipped with general knowledge but religious sciences that will be useful for learners in interacting in their lives (Fahmi, 2020b).

The third Islamic moderating value is tasāmuh (tolerance). In internalizing the value of tolerance in PAI learning at SMA Ma'arif NU 1 Kemranjen was by group discussion activities, group division, group spokesperson appointment, group cooperation, class leader selection, picket group division, class rule making and through learning materials. Group working activities that begin with the division of groups will foster the process of group discussion because the teacher let students free to choose their own group. When learners choose their own group, it will give an example of not imposing our will to others, which represents tolerance (Fahmi, 2020c)

From the presentation, it is known that the internalization of Islamic moderation values in learning activities at SMA Ma'arif NU 1 Kemranjen was carried out through three stages of value internalization as well as the stages used in internalizing the value of character education. The three stages are value transformation, value transactions, and value trans-internalization (Muhaimin, 2001: 153). At the stage of value transformation, values were delivered verbally. The role of the teacher was simply to inform the good and the bad values to the students. At the value transaction stage, value internalization is conducted in two-way communication. It does not only convey information about good and bad value, but also implement and provide exemplify those values in daily life, in which students are asked to respond by receiving and practicing the value. At the transinternationalization stage, the teacher's presence before their students is not just physical, but more of mentality, attitude, and personality. Likewise, learners respond not only in movement and appearance, but manifest the values in their attitudes and 
behaviors. Therefore, this transinternationalization stage is the communication of two personalities who are each actively and reactively involved.

\section{Internalization of Islamic Modern Values through Religious Activities}

The internalization process of Islamic moderation values is also carried out through religious activities. Each school has different religious activities. SMA Ma'arif NU 1 Kemranjen in internalizing the value of Islamic moderation through a program of religious activities was divided into three stages; the introduction of Islamic moderation values, the enlightening of moderation values, and the practice of Islamic moderation values.

Activities to introduce the value of Islamic moderation through Istigasah activities in religious activities are given by understanding the examples of attitudes given by messenger of Allah SAW to his companions and to his people. The appreciation of the value of Islamic moderation is more towards fostering a sense of the importance of having the value of Islamic moderation in students, and the practice of the value of Islamic moderation values emphasizes more on interaction with all school residents (Fahmi, 2020a)

There are three components needed in the formation of one's attitude as mentioned in Thomas Lickhona's theory of attitude formation. The three components are moral knowing related to cognitive aspects, moral feeling that is closely related to affective aspects, and moral action which is a tangible manifestation of psychomotor aspects (Idris, 2019: 100). The connection between the three components initiated by Thomas Lickhona can be attributed in the formation of attitudes in general and applies in instilling the values of Islamic moderation education in SMA Ma'arif NU 1 Kemranjen. The internalization of Islamic moderation values through religious activities, as Muhaimin conveyed that the stages of internalization of values in value education, including in this case the modern value of Islam, namely the transformation of values, value transactions, and trans-internalization of values.

First, the stage of value transformation in various religious activities carried out at SMA Ma'arif NU 1 Kemranjen.
At this stage Islamic moderation values were introduced through lectures or advice activities. Lectures were conducted in conjunction with religious activities such as after istigasah, Yasin and Tahlil or during Islamic holidays. At this stage of value transformation, students would gain knowledge about Islamic moderation values through lectures and advice. This indicates an early stage in the process of transforming the value of Islamic moderation.

Second, the value transaction stage in religious activities can be seen from the process of habituation of religious activities, such as $3 \mathrm{~S}$ culture (smiles, greetings, such as say helo, and greetings in Islam as well, habituation of religious activities such as Duha prayer, Zuhur jama'ah prayer, istigasah, and read yasin and tahlil. In addition, the method of civility that the teachers carry out makes students realize and feel the importance of Islamic moderation value. This habituation and civility activity are stages of transaction of Islamic moderation value in religious activities as conveyed by Muhaimin that the value transaction stage is the stage to conduct two-way communication or interaction between teachers and students of a reciprocal nature (Muhaimin, 2001: 153-154). Through habituation and civility, interaction will arise through activities that become religious activities so that it will be effective in internalizing the value of Islamic moderation.

Third, the analysis stage of trans internalization of values at SMA Ma'arif NU 1 Kemranjen in religious activities. The transinternalization stage of value is a situation where students are independently able to apply the value of Islamic moderation in life as early as they could. The transinternalization stage of grades at SMA Ma'arif NU 1 Kemranjen can be seen from the manners of students both to friends, teachers and even guests, social care by donating some of the property during social service or raising funds to help friends or teachers who are affected by disasters, solving problems by prioritizing deliberation in learning, helping distressed friends by showing moderate attitudes in the classroom, performing worship without being told or forced, and always appreciating and respecting the differences that exist among the school community. 


\section{Internalization of Islamic Moderation Values in the learning of local Aswaja and ke-NU-an content.}

As PAI learning instills the value of Islamic moderation in every learning, local content at SMA Ma'arif NU 1 Kemranjen also instilled the value of Islamic moderation in every learning. Local content was learning Aswaja or Ke-NU-an. Islamic moderation values such as justice, balance, and tolerance are internalized through subject matter. While in learning Aswaja is almost the same as the learning PAI only the value of Islamic moderation instilled is the basic value because basically the value of justice, balance, and tolerance is the description of the value of Aswaja i.e. tawāsut (moderate), tawāzun (balanced), i'tidāl (fair), and tasāmuh (tolerant) is the basic principle of Islamic moderation value (Misbah, 2019: 102). The stages of internalization process of values in Aswaja learning are as follows:

First is the value transformational stage. At this stage the value of Islamic moderation was given verbally by the teacher in learning along with the story of the Prophet's civility that reflects the attitude of Islamic moderation. In addition, giving advice or lectures in religious activities was also a process of value transformation. This is in accordance with Muhaimin's theory of the stage of value transformation where students will be introduced to good and bad values verbally.

Second is the value transactional stage. In the transaction stage of Islamic moderation value in the learning of local Aswaja content at SMA Ma'arif NU 1 Kemranjen in the learning process was conducted by discussion and question and also answer methods related to Aswaja material. In the discussion there will be two-way communication between teachers and students, so that the internalization process run two-way. In this stage, students got motivated to be confident and dare to express opinions. Finally, there are students who dare to ask questions and become interested in the discussions in the class because other students respond.

Third was the trans internalization stage of the value. In the process of trans internalizing the value of Islamic moderation in learning Aswaja students will apply the
Islamic moderation value that they already have in daily life. At SMA Ma'arif NU 1 Kemranjen, there was a forum to apply the value of Islamic moderation, namely Nahdlatul Ulama learning organization or called IPNU-IPPNU organization which was established as a forum for student organizations for students to apply the value of Islamic moderation in accordance with the teachings of Aswaja. In addition, the value of Islamic moderation was applied through read Yasin and Tahlil activities, istigasah, social service, and the personality of everyday students. This is in accordance with muhaimin's theory (1996) which states that the trans internalization stage of value is a stage that is not only a knowledge of value but already in the process of applying value in life and becoming a character.

\section{Internalization Strategy of Islamic Moderation Values in PAI Learning at SMA Ma'arif NU 1 Kemranjen}

In the previous data exposure in accordance with the data obtained by the author, the strategies used by teachers in internalizing the value were:

\section{Introduction}

At this stage of internalization, the understanding of which values are of Islamic moderation was given to students. This was conducted during learning, either in PAI or Aswaja learning, through lectures during istigasah or desperation activities, through advice when students to students or through learning materials (Fahmi, 2020b).

\section{Habituation}

The values that already exist in learners should be used with routine activities because something that is used will be lived and impregnated in the self then give rise to a sense of the importance of the value in life. Repetitive activities will become a habit and become a religious activity, and it will have an impact in implementing a value. At SMA Ma'arif NU 1 Kemranjen one of the strategies in internalizing the value of Islamic moderation was through habituation methods, the goal was to make students can feel the value of moderation and be aware of the importance of moderation value in life. The habituation was: $3 \mathrm{~S}$ culture (smiles, greetings, and greetings in Islam (salam)), congregational prayers, istigasah, yasin and 
tahlil, Keputrian, social service and culture of manners (Fahmi, 2020a)

\section{Conscientiousness}

The value that had been received and appreciated by the students, there should be a real example of a teacher so that students can see a real picture of a value exemplified by the teacher. Conscientiousness was one of the effective ways in the process of internalizing a value in students. This is because educators are the most tangible example to be treated and emulated by learners in all behaviors and speech. At SMA Ma'arif NU 1 Kemranjen teachers exemplify the value of Islamic moderation with discipline, tolerant, fair to all students, solving problems by way of deliberation and respect the differences (Fahmi, 2020b).

\section{Practice}

The values that students already have will be seen if the value is practiced in daily life without any orders and coercion. If it has been done, then the child has formed a personality of that value. As at SMA Ma'arif NU 1 Kemranjen the students were automatically accustomed to doing worship without being ordered, doing religious activities such as istigasah was also on time without being ruled by the teacher. In addition to the student's care, also very high such as raising funds to help friends or teachers affected by disasters, helping friends who were in troubled, respect the differences when there were friends who were adherenst of different religious organizations, respect each other in class discussions, and courtesy to friends and teachers even to school guests (Fahmi, 2020c).

Internalization strategy was carried out starting from the introduction of the value of Islamic moderation that was classified as good and not good, then the value was appreciated through habituation with religious activities, then the activity is used in daily life, and to know that the value has been integrated in the student then can be seen from the value of Islamic moderation applied every day without any orders or coercion.

From the above presentation, it can be concluded that the strategy of internalizing Islamic moderation values begins with the introduction of Islamic moderation values. Afterwards, the students received value transferred from teachers through lectures both in learning and school religious activities, through PAI materials and Aswaja as well as desperation. Furthermore, the value was appreciated by students by conducting religious activities such as $3 \mathrm{~S}$ culture (smiles, greetings, and greetings (salam)), culture of manners, Duha praying, pray Zuhur together, istigasah, yasin and tahlil, desperation, social service, and Islamic Great Day Commemoration. Then these activities were deepened by the exemplary role exemplified by the teacher. These activities were then used every day until finally students practice the value of Islamic moderation in daily life.

\section{Implications of Internalization of Islamic Moderation Values in PAI learning on Social Attitudes of Students at SMA Ma'arif NU 1 Kemranjen}

Attitude means a way of action against a inducement. According to Muhibbin Shah who quoted his opinion, Bruno said that attitude is a relatively sedentary tendency to react in a good or bad way to certain people or goods (Syah, 2002: 120). Thus, attitude is a person's tendency to act in a certain way that can be manifested in the form of children's learning behavior characterized by the emergence of new tendencies that have changed towards an object, value, or event.

The word societies from the word socius which means friend, and furthermore the word social means the relationship between human beings in different forms, such as : family, organization, school, group, and so forth (Sujanto, 2004: 236). Social attitudes in general can be interpreted as the relationship between human beings and other human beings, interdependence with other humans in various aspects of community life, as reviewed from a psychosocial (social psychiatric) angle, social attitudes are an effort to cultivate human resources through the process of interpersonal relationship (inter-individual relationships) that take place in an organized community environment.

Based on the results of the study, the implications of internalization of Islamic moderation values in PAI learning to the social attitudes of students at SMA Ma'arif NU 1 Kemranjen has positive implications. The focus of this research is on the development of student attitudes and habits conducted in schools as well as the awareness raised by teachers from various supportive 
activities in the school, from which it can be concluded that the implications of internalization of Islamic moderation values to the social attitudes of students at SMA Ma'arif NU 1 Kemranjen are as follows:

1. Students have a fair attitude. The students at SMA Ma'arif NU 1 Kemranjen have a fair attitude, both fair to Allah SWT, fair to themselves, fair to others, and fair to all creatures of Allah SWT. This is evidenced by students diligently worshipping, not feeling right themselves, not demeaning others because of different views, and keeping the school environment conducive.

2. Students have balanced thinking. Balance in thinking is not extreme left or extreme right, not only the science of the world but also the science of the hereafter. And this is evidenced by the school's curricular program and also the religious program at SMA Ma'arif NU 1 Kemranjen.

3. Students show tolerating attitudes. Students that show an attitude that always respects and do not underestimate others, nor show a disdain towards fellow Beings of God such as respecting teachers and friends, saying politely when talking to teachers, bowing when walking in front of teachers, not like to insult friends, let alone until quarreling, and hostile.

4. Students display social care such as the disbursement of funds to help friends or teachers who are being hit by a disaster, social service, offer a ride to a friend, sharing food to friends.

5. Students show tolerating behaviors, like staying close friends even with friends of different religious organizations, respecting each other's differences, not blaming the worship of others. This is proven in group discussions, not insulting or blaming the understanding of others.

6. Honesty. Behavior based on efforts so that he can always be believed in words and actions, both for himself and others is evidenced by when the test or test always do itself and not cheating, judging by the assessment of social attitudes also done by the teacher shows an honesty attitude among his students.
7. Students are being disciplined and confident, such as come to school not too late, help events or activities in the community and together with community make an event to facilitate the big day of Islam.

8. Students obey the rules both in school and in the community, such as not participating in doodles at graduation, not committing acts that violate the law or norms in the community.

\section{CLOSING}

There are three forms of internalization of Islamic moderation values implemented at SMA Ma'arif NU 1 Kemranjen Banyumas, namely through PAI learning in the classroom, religious activities, and local content, namely Aswaja and ke-NUan learning. The value of Islamic moderation internalized through PAI learning is the value of justice ('adālah), balance (tawāzun), and tolerance (tasāmuh). This study shows that there are three stages conducted by SMA Ma'arif NU 1 Kemranjen in carrying out the internalization of Islamic moderation values, namely: the stage of value transformation, the stage of value transactions, and the trans internalization stage of values.

The internalization phase of Islamic moderation values in PAI learning activities is carried out in three stages. The first stage is the transformation of values that introduces the value of Islamic moderation to students. The second stage is value transactions, namely the appreciation of Islamic moderation value to students. The third stage is trans-internalization. The transinternalization stage is done with verbal communication, and also through mentality and personality as well as attitudes and Islamic moderation values will be applied in daily life. Such learners have an attitude of justice, balanced, tolerance, social care, and discipline in worship and manner.

The strategy conducted at SMA Ma'arif NU 1 Kemranjen in PAI learning employed four strategies, namely introduction, habituation, civility, and practice. The four strategies of internalization of Islamic moderation value are divided into internalization stages, the level of value transformation contained in the introduction strategy; the value transaction stage 
contained in the habituation and civilization strategy; and the value transformation stage contained in the value practice strategy.

The implications of internalizing Islamic moderation values to the social attitudes of students at SMA Ma'arif NU 1 Kemranjen include having a proper, balanced, tolerant, honest, social care, discipline, confident, and rule-abiding attitude.

The author hopes more academics will carry out research on the internalization of Islamic moderation values with the object of more in-depth study. Also, SMA Ma'arif NU 1 Kemranjen would always improve the quality of educational character, especially in internalizing the values of Islamic moderation to the students, because this school already has an internalization strategy of Islamic moderation values and this is very effective in shaping the moderate character of students and ultimately impacting the social attitudes of students.

\section{ACKNOWLEDGEMENTS}

The researchers fully realized that during this study found many challenges and obstacles must be faced. Still, thanks to encouragement, guidance, and cooperation with various parties, all of them are able to overcome. Therefore, we express our gratitude and high appreciation to those who have helped in the writing process; all teachers and staff employees of SMA Ma'arif NU 1 Kemranjen Banyumas, who have provided assistance. In addition, thank you to the Principal Mr. H. Sabar Zuhdi, S.Pd.I, deputy principal of the curriculum section Mr. Muntoha Asnawi, S.E, PAI Teacher Mr. Mahmud Yunus, S.Pd.I. and Also The Head of Administration Mr. Moch. Fathurozak. Thank you for the help and cooperation during the research at SMA Ma'arif NU 1 Kemranjen. All students of SMA Ma'arif NU 1 Kemranjen, who have provided data and information so that this research can be completed.

\section{REFERENCES}

\footnotetext{
Amaliyah, E. I. (2020). MAKNA KEBERAGAMAAN MAHASISWA PENERIMA BEASISWA STAIN. 18(3), 326-337.

https://doi.org/http://dx.doi.org/10.3272
}

9/edukasi.v18i3.635

Anwar, S. (2014). Desain Pendidikan Agama Islam (Konsep dan Aplikasinya dalam Pembelajaran di Sekolah). Idea Press.

Beryandhi, M. (2020). Media Baru dan Fenomena Hate Speech di Indonesia: Media Penyakit Sosial Baru. Kumparan. https://kumparan.com/mohamadberyandhi/media-baru-dan-fenomenahate-speech-di-indonesia-mediapenyakit-sosial-baru-1uTKOats1y9

Carina, J. (2019). KALEIDOSKOP 2019: Sejumlah Teror yang Guncang Indonesia, Bom Bunuh Diri hingga Penusukan Wiranto. Kompas. https://nasional.kompas.com/read/2019/ 12/25/07485601/kaleidoskop-2019sejumlah-teror-yang-guncangindonesia-bom-bunuh-dirihingga? page $=$ all

DIKBUD, B. (2003). Undang-undang Sistem Pendidikan Nasional. In Acta Pcediatrica. https://doi.org/10.1111/j.16512227.1982.tb08455.x

Fahmi, I. N. (2020a). Interview dengan $H$. Sabar Zuhdi, S.Pd.I.

Fahmi, I. N. (2020b). Interview dengan Mahmud Yunus, S.Pd.I.

Fahmi, I. N. (2020c). Observasi di kelas XII IPS 2 dalam pembelajaran PAI.

Harto, K., \& Tastin, T. (2019). Pengembangan Pembelajaran Pai Berwawasan Islam Wasatiyah : Upaya Membangun Sikap Moderasi Beragama Peserta Didik. AtTa'lim: Media Informasi Pendidikan Islam, $\quad 18(1), \quad 89$. https://doi.org/10.29300/attalim.v18i1.1 280

Herdyansah, H. (2019). Metode Penelitian Kualitatif untuk Ilmu-Ilmu Sosial: Perspektif Konvensional dan Kontemporer. Salemba Humanika. http://www.penerbitsalemba.com

Hiqmatunnisa, H., \& Zafi, A. A. (2020). Penerapan Nilai-Nilai Moderasi Islam Dalam Pembelajaran Fiqih di PTKIN Menggunakan Konsep Problem Basic Learning. Jipis, 29(1), 27-35. https://doi.org/https://doi.org/10.33592/ jipis.v29i1.546

Idris, M. (2018). Pendidikan Karakter: Perspektif Islam dan Thomas Lickona. Ta'dibi: Jurnal Manajemen Pendidikan Islam, $\quad \operatorname{VII}(1), \quad$ 77-102. https://www.google.com/amp/s/m.liputa n6.com/amp/2661828/kronologitawuran-bocah-sd- 
Ismail, S., Saepulmillah, A., Ruswandi, U., \& Arifin, B. S. (2019). Analisis Kritik Terhadap Pelaksanaan Pembelajaran PAI di Sekolah. Jurnal Pendidikan Islam, 10(November), 43-51. https://doi.org/https://doi.org/10.22236/ jpi.v11i2.5901

KEMENDIKBUD RI. (2014). Permendikbud Nomor 81 A 2013. Implementasi Kurikulum Kurikulum, 1, 1-97.

Kementerian Agama RI. (2012). Moderasi Beragama. Lajnah Pentashihan Mushaf Alquran Kementerian Agama RI,.

Misbah, M. (2019a). Habituasi Nilai-Nilai Islam Inklusif $\mathrm{Di}$ Pesantren Ma'Hadutholabah Dan Darul Khair Babakan Tegal Inclusive. Jurnal "AlQalam, 25(1), 93-106. https://doi.org/http://dx.doi.org/10.3196 9/alq.v25i1.701

Misbah, M. (2019b). Pergeseran Pemikiran Pendidikan Islam Antar Generasi. STAIN Press.

Moleong, L. J. (2010). Metode Penelitian Kualitatif. PT Remaja Rosdakarya.

Muhaimin. (2001). Paradigma Pendidikan Islam, Upaya Mengefektifkan Pendidikan Agama Islam di Sekolah. PT Remaja Rosdakarya.

Mulyasa, E. (2011). Manajemen pendidikan Karakter. Rosdakarya.

Muslim, A. (2019). Curhat Di Balik Laci: Ekspresi Literasi Siswa Di Madrasah Aliyah Pesri Kendari. Al-Qalam, 25(1), 211-224.

Muslim, A., Idham, I., \& Subair, M. (2019). Iko Iko Siala Tangang (Tracing Moderatism of Religious Concept From the Oral Traditions of Bajau). In International Conference on Religion and Education.

Nuqtoh, H. (2015). Standar Nasional PAI Lahir DAri Kritik. Kompasiana. https://www.kompasiana.com/hamdi/55 0e7f31813311842cbc652d/standarnasional-pai-lahir-dari-kritik

Penyusun, T. (2019). Moderasi Beragama. In Kementerian Agama (Vol. 53, Issue 9). Badan Litbang dan Diklat Kementerian Agama RI.
Purwanto, Y., Ma, D., Fauzi, R., \& Diterima, N. (2019). 166403 Pusat Penelitian dan Pengembangan Kementerian Agama RI. Edukasi, $\quad$ 17(2), 110-124. https://doi.org/http://dx.doi.org/10.3272 9/edukasi.v17i2.605

Saefudin, L. H. (2018). seminar "Pentingnya Moderasi bagi guru Pendidikan Agama."

Setioko, B. (2011). Penggunaan Metoda Grounded Theory Dibawah Payung Paradigma Postpositivistik. Jurnal Arsitektur: Modul, 11(01), 1-6. https://doi.org/https://doi.org/10.14710/ mdl.11.1.2011.\%25p

Sugiyono. (2015). Metode Penelitian Pendidikan (Pendekatan Kuantitatif, Kualitatif dan $R \& D)$. Alfabeta.

Suharto, T. (2017). Indonesianisasi Islam: Penguatan Islam Moderat dalam Lembaga Pendidikan Islam di Indonesia. Al-Tahrir: Jurnal Pemikiran Islam, 17(1), 155-178. https://doi.org/10.21154/alt ahrir.v17i1.8 03

Sujanto, A. (2004). Psikologi Umum (10th ed.). Rineka Cipta.

Suprapto. (2020). Integrasi Moderasi Beragama Dalam Pegembangan Kurikulum Pendidikan Agama Islam Integration of Religious Moderation in the Development of. 18(3), 355-368. https://doi.org/http://dx.doi.org/10.3272 9/edukasi.v18i3.750

Syah, M. (2002). Psikologi Pendidikan dengan Pendekatan Baru. PT Remaja Rosdakarya.

Wardani. (2020). Moderasi Beragama. LP2M UIN Antasari Banjarmasin. https://www.uinantasari.ac.id/moderasi-beragama/

Yunita, N. W. (2005). Sidik Jari Santri, Kalla Soroti Sikap Sensitif Tanpa Alasan. DetikNews. 